\title{
Population analyses of microfauna at a Water treatment Plant at Shebeen Alkoom, Minufeya, Egypt.
}

\section{Mansour Galal $^{1}$; Elsayed A. Khallaf ${ }^{1}$; S. El-Sbbagh ${ }^{2}$ and Noura M. Nabet ${ }^{1}$}

1- Zoology Dept, Faculty of Science, Minufeya University, Shebeen Alkoom, Egypt.

2- Botany Dept, Faculty of Science, Minufeya University, Shebeen Alkoom, Egypt.

\section{ABSTRACT}

Safe Drinking water is a priority for human health all over the world. Accordingly, the microfauna of raw, filtered, treated, and tap water were investigated in this study. The results proved the efficiency of the Water Plant, but slight occurrence of non-pathogenic bacteria in tap water, indicated the necessity to renovate the distribution system.

Most of the physico-chemical characters are within the standards for drinking water apart from phosphate, nitrate, iron and manganese. Raw water samples only were positive for E. coli, T. \& F. coliform, Salmonella and Shigella. This could be referred to the illegal discharge of sewage and other organic pollutants into the water source. Sixty one protozoan genera were identified only in raw water which can be attributed to the influence of chlorination during water treatment. Ciliated protozoan densities proved seasonal variation with highest values during Autumn. Protozoan monthly densities showed significant correlations with certain physical and chemical parameters. Therefore ciliates are considered as bio-indicators for pollution in various aquatic habitats. Simultaneously, rotifers can be used to indicate the performance level of certain stages of water treatment process as they showed significant correlations with different ecological factors.

Keywords: Fecal bacteria, Protozoa, Water-treatment.

\section{INTRODUCTION}

Micro-organisms play an important role in nutrient recycling in nature with particular reference in aquatic ecosystems. Bacteria oxidize the highly complicated organic materials into simpler inorganic salts which are useful to biotic and abiotic components of the aquatic ecosystems. Protozoan organisms help directly and indirectly in both nutrient recycling and removal of different types of pollutants. This was carried out through the predation of bacteria and consequently keeping bacteria in permanent biological activity. On the other hand, different protozoa feed upon pathogenic and harmful bacteria like fecal type.

\section{MATERIAL AND METHODS}

\section{Study Area}

The study included the different stages of water treatment at Shebeen Alkoom Water Treatment Plant. It is located south of the city and feeds the western side of the city.

\section{Sample Determinations and Collection Procedures}

Water samples for microbiological analysis were collected aseptically in $500 \mathrm{ml}$ glass bottles containing $1 \mathrm{ml}$ of $3 \%$ freshly prepared sodium thiosulphate solution $\left(\mathrm{Na}_{2} \mathrm{~S}_{2} \mathrm{O}_{3}\right)$ to neutralize the residual chlorine. The samples were preserved in ice box during transportation (APHA, 1998), brought to the laboratory three times monthly 
during a period from November 2008 to November 2009 and examined within 6 hours of collection. For physico-chemical analysis the samples were collected in 1 liter glass bottles.

\section{Physio-chemical Characteristics}

Turbidity

Turbidity is an expression of the amount of light scattered and absorbed by the particles in a sample and is measured as "Nephelometric turbidity units" (NTU) by using turbidity meter (PCH019054, Germany).

\section{Chemical Characteristics}

The chemical analyses were carried out in the laboratory at faculty of scienceMinofia University. The study of the chemical properties of the water included.

\section{Hydrogen Ion Concentration (pH)}

The $\mathrm{pH}$ values of the collected field samples are determined by the use of benchtop pH/Ion Meter (Model 6500, China).

\section{Determination of Hardness (Calcium and Magnesium)}

The hardness of water is a measure of the concentration of calcium and magnesium salts dissolved in water. Calcium and magnesium in water samples were determined using EDTA (Ethylene diamine tetra acetate) titrimetric method according to APHA (1998).

\section{Dissolved Oxygen (DO)}

The oxygen content of the water samples was measured by SB70D DO Bench top meter S/NDO 0800, U.S.A. and expressed as $\mathrm{mg} / \mathrm{L}$.

Ammonia $\left(\mathrm{NH}_{3}\right)$, nitrite $\left(\mathrm{NO}_{2}\right)$, nitrate $\left(\mathrm{NO}_{3}\right)$, phosphate (Po4), silica (Si), iron $(\mathrm{Fe})$, manganese $(\mathrm{Mn})$ and fluoride $(\mathrm{Fl})$ contents were determined using assay colorimetric kits (HANNA instrument, C200 Multiparameter Ion Specific Meter, Hungary) according to the manufacture's protocols. The results were expressed as $\mathrm{mg} / \mathrm{l}$.

\section{Biological Examination Zooplankton}

Samples for analysis of zooplankton were collected from the studied four stages (raw water- filtered water - treated water - tap water) into glass bottles of $500 \mathrm{ml}$ capacity. In the laboratory, water sample in each bottle was mixed well by inverting the bottle at least ten times smoothly, then for each stage, three replicates each of 10 ml were taken, centrifuged by using a cooling centrifuge (Hermle, Z252 MK, Germany) for three minutes at $7{ }^{\circ} \mathrm{C}$ and at $1500 \mathrm{rpm}$. The volume of each replicate was concentrated to three $\mathrm{ml}$ by decanting the supernatant and the residual was transferred to a cavity slide drop by drop and then the different zooplankton organisms were counted by using a Carl Zeiss transmitted light inverted Microscope, Germany. The identification was performed according to Patterson and Hedley (1996). The results were expressed as organism $\times 10^{3} / 1$.

\section{Bacteria}

\section{Enumeration of Indicator Organisms}

Water samples were analyzed for total coliform (TC), fecal coliform (FC) and E. coli using Most Propable Number (MPN/100 ml according to Boothman et al., 2002 and Michiels and Moyson; 2000). This method was given in Standard Methods for Examination of Water and Wastewater (AHPA, 1998).

For TC counts a series of five fermentation tubes containing $10 \mathrm{ml}$ double strength lauryl tryptose broth (LTB) (Merck) were inoculated with $10 \mathrm{ml}$ volumes of water samples (treated water, tap water). In the examination of the non-potable water (raw water) 1.0, 0.1, $0.01 \mathrm{ml}$ portion of the sample was used as inoculum for a series 
of five fermentation tubes containing $5 \mathrm{ml}$ single strength lauryl tryptose broth. The tubes were incubated at $37{ }^{\circ} \mathrm{C}$ for $48 \mathrm{~h}$. All gas positive (yellow) LTB tubes were subcultured to tubes of brilliant green lactose bile broth (BGLB, Merck), and incubated at $37{ }^{\circ} \mathrm{C}$ for $48 \mathrm{~h}$. Gas-positive BGLB tubes were considered positive for the presence of TCs. Gas-positive LTB tubes were subjected to further analysis with $E$ coli broth (Merck). The Ec tubes were incubated at $44.5^{\circ} \mathrm{C}$ for 24 h. E. coli positive tubes were confirmed for the presence of $E$. coli by performing Gram stain. All cultures appeared as Gram-negative, short rods re-inoculated back into LTB to confirm gas production.

Water samples were analyzed for bacterial indicators, Salmonella and Shigella by using Deoxycholate citrate agar. It is a modification of deoxycholate agar formulated by Leifson (1935) and modified by Hynes (1942). The results are expressed as CFU/ ml (APHA, 1998).

\section{Principles of the Procedure}

Meat extract and meat peptone provides the nitrogen and vitamin sources in Deoxycholate Citrate Agar. Lactose is the fermentable carbohydrate. Sodium Deoxycholate and Sodium Citrate inhibit growth of Gram-positive bacteria, coliforms and Proteus spp. Ferric Citrate aids in the detection of $\mathrm{H}_{2} \mathrm{~S}$ producing bacteria. Neutral Red is a pH indicator. Agar is the solidifying agent.

In the presence of Neutral Red, bacteria that ferment lactose produce acid and form red colonies. Bacteria that do not ferment lactose form colorless colonies. If bacteria produce $\mathrm{H}_{2} \mathrm{~S}$, colonies will have black centers. The majority of normal intestinal bacteria ferment lactose and do not produce $\mathrm{H}_{2} \mathrm{~S}$ (red colonies without black centers). Salmonella spp. and Shigella spp. do not ferment lactose, but Salmonella may produce $\mathrm{H}_{2} \mathrm{~S}$ (colorless colonies with or without black centers). Lactosefermenting colonies may have a zone of precipitation around them caused by the precipitation of deoxycholate in the presence of acid.

Sodium desoxycholate and sodium citrate present in the medium inhibit the growth of the Gram positive bacteria. Lactose fermenting bacteria cultivate with pink colonies surrounded by a zone of precipitated bile salts. Lactose non fermenting bacteria cultivate with colorless colonies, with or without a black center caused by the production of hydrogen sulphide, as illustrated in Table 1.

Table 1: Culture Response on Desoxycholate Citrate Agar at $35^{\circ} \mathrm{C}$ after 48 Hours Incubation*.

\begin{tabular}{|l|l|l|}
\hline Organisms (ATCC) & Growth & Color of colony \\
\hline Salmonella typhi (6539) & +++ & colorless to tan \\
\hline Salmonella typhimurium (14028) & +++ & colorless to tan \\
\hline Salmonella enteritidis (13076) & +++ & black centered \\
\hline Shigella sonnei (25931) & ++ & colorless to pink \\
\hline Shigella flexneri (12022) & ++ & colorless to pink \\
\hline Escherichia coli (25922) & \pm & Pink with zone of precipitation \\
\hline Enterococcus faecalis (29212) & - & - \\
\hline
\end{tabular}

\section{Statistical Analysis}

Statistical Analysis was carried out at $1 \%$ and $5 \%$ level of significance. The correlation and regression coefficients were carried out using Microsoft Office Excel and Statistical Package for the Social Sciences (SPSS) version 15. 


\section{RESULTS}

\section{Zooplankton Distribution}

Zooplankton groups occurred only in raw water samples and were completely absent in filtered, treated and tap water samples. This might be attributed to the effect of pre-chlorination during water treatment process in the plant.

Abundant Zooplankton (x $10^{3}$ )

In the present investigation as illustrated in Table 2, seasonal variation of the most abundant zooplankton groups attained a high number of 1722 in Autumn, and the second peak of 1611 in Spring, while the minimum value of 1048 was observed in Winter.

Table 2: Seasonal Variation of the Most Abundant Zooplankton Group (X10 $3 / \mathrm{L}$ )

\begin{tabular}{|c|c|c|c|c|c|c|}
\hline Season & $\begin{array}{c}\text { Sum of } \\
\text { Sarcodines }\end{array}$ & $\begin{array}{c}\text { Sum of } \\
\text { Flagellates }\end{array}$ & $\begin{array}{l}\text { Sum of } \\
\text { Ciliates }\end{array}$ & $\begin{array}{c}\text { Total } \\
\text { Protozoa }\end{array}$ & Rotifers & $\begin{array}{c}\text { Protozoa \& Rotifera } \\
\text { as main Zooplankton } \\
\text { Groups }\end{array}$ \\
\hline Winter & 255 & 159 & 570 & 984 & 64 & 1048 \\
\hline Spring & 285 & 234 & 905 & 1424 & 187 & 1611 \\
\hline Summer & 377 & 77 & 877 & 1331 & 196 & 1527 \\
\hline Autumn & 289 & 174 & 1143 & 1606 & 116 & 1722 \\
\hline Total & $\begin{array}{c}1206 \\
(23 \%)\end{array}$ & $\begin{array}{c}644 \\
(12 \%)\end{array}$ & $\begin{array}{c}3495 \\
(65 \%)\end{array}$ & $\begin{array}{c}5345 \\
(90.5 \%)\end{array}$ & $\begin{array}{c}563 \\
(9.5 \%)\end{array}$ & 5908 \\
\hline
\end{tabular}

Zooplankton populations are differentiated into many groups. The most abundant are protozoa and rotifera. Their percentage frequencies are $90.5 \%$ and $9.5 \%$, respectively.

\section{Total Protozoa}

Protozoa persisted all over the year in the collected water samples. A total of 61 genera were identified, 42 genera of ciliates, 12 genera of phytoflagellates and 7 genera of sarcodines, in raw water samples of the studied area, as shown in Table 3.

The monthly variations of total density of protozoa in raw water are given in Table 4. It was found that population density of protozoa in raw water attained a climax of 730 organism $\times 10^{3} / 1$ in September, the second peak 719 organism $\times 10^{3} / 1$ was observed in April, while the minimal value (266 organism $\times 10^{3} / 1$ ) was detected in February.

Table 3: Identified Genera of Protozoa.

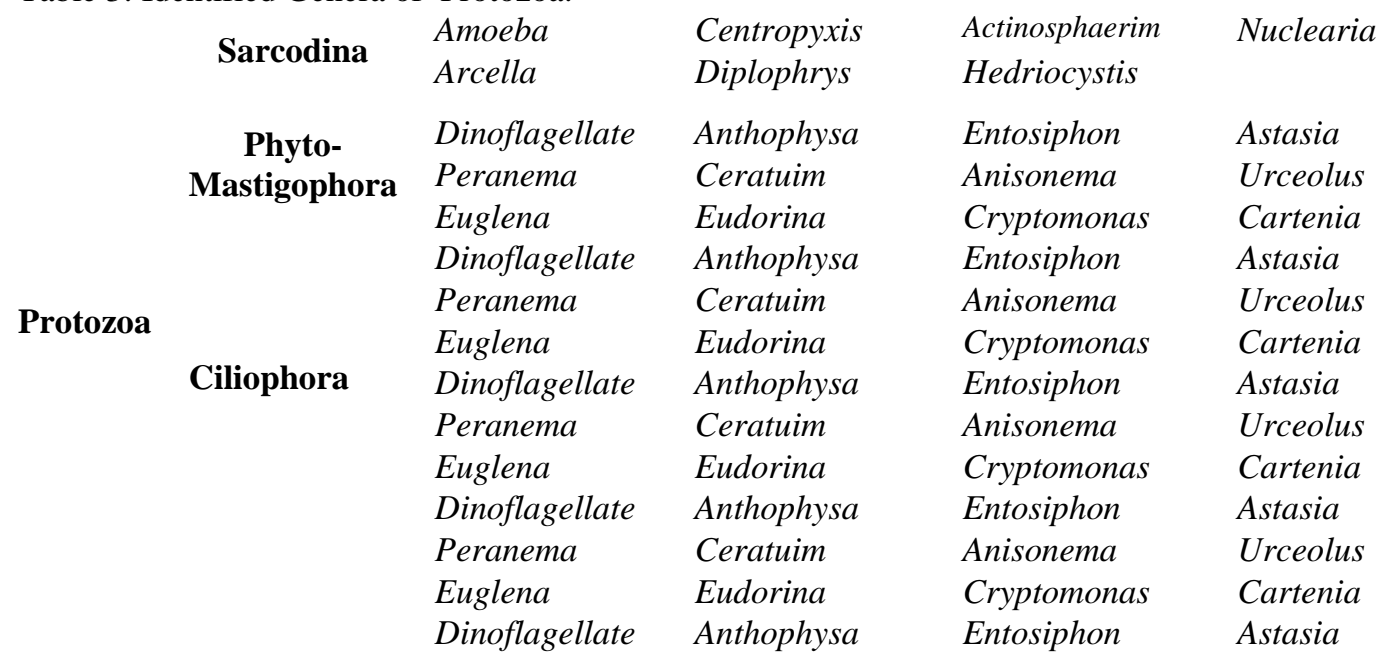




\section{Common, Frequent and Rare Protozoa (number of organisms x 10 ${ }^{3}$ ).}

The common genera of protozoa in raw water samples, were represented by thirteen genera. These genera were Amaeba sp., Arcella sp., Actinosphaerium sp., Centropyxis sp., Peranema sp., Anisonema sp., Cryptomonas sp., Vorticella sp., Paramecium sp., Cinetochilum sp., Aspidisca sp., Tachysoma sp., and Cyclidium sp. They contributed different percentages among the total protozoan numerical density (5345 organism $\left.\times 10^{3} / l\right)$.

The results also revealed that, Amaeba reached a maximum of 89 in July and a minimum of 13 in February. The maximum population density of Arcella sp. was 78, recorded in June, while it was not easily detected in May. The population density of Actinosphaerium sp. ranged between a maximal value of 77 in Jan and minimal value of 3 in August. The maximum population density of Centropyxis was 81 on August, while it couldn't be detected in January, February, March, April, May and July. Peranema sp. reached its maximal count of 54 during April and it was more or less absent during August.

Anisonema sp. reached a maximum value of 70 in September and it was missing in December, May and November. Cryptomonas sp. reached a climax of 57 in January, while it could not be easily detected in December, May, July, August, September, October and November. Vorticella sp. reached its maximal count of 83 in September and minimal count of 3 in December. Paramecium reached a climax of 39 in November, while the minimal value of 1 detected in September. Cinetochilum sp. attained a maximal population density of 190 in September, while it could not be detected in December, January, February and August.

Aspidisca sp. population density ranged between a maximal value of 127 in September and minimal value of 6 in February. Tachysoma sp. and Cyclidium sp. reached a maximal value of 151 in April and 184 in June respectively. Tachysoma sp. could not be detected in May, June and August, while Cyclidium sp. was absent during August.

\section{Genera of frequent Protozoa}

These were represented by eight genera: Dinoflagenate, Euglena, Chilodonella sp., Halteria sp., Lembadion sp., Litonotus sp., Strombilidium sp. and mesodinium sp. They contributed various percentages of the total protozoa (5345 organism $\times 10^{3} / 1$ ).

Dinoflagellate sp. reached a maximum value of 13 in September and completely missed in May. Euglena peaked with a value of 17 in May, but was absent during March and August.

Halteria sp. reached a climax of 41 in March, while it was not found in December, January, April, June, October and November. Lembadion sp. reached a maximum value of 36 in March and missed during April, June, July, August and September. Litonotus sp. reached 36 in April and September, while it could not be detected in May, July, August, and October.

Chilodonella sp. reached a climax of 37 in August and difficult to be sampled in December, January, February, March, April, May, July and October. Strombilidium sp. reached about 31 in January, while it could not be detected in December, April, May, June and July. Mesodinium sp. population density reached 32 in July, while it could not be easily detected during December, February, March, and May.

\section{Rare Genera of Protozoa}

These were represented by 40 genera having varying percentages among the total protozoa (5345 organism $\times 10^{3} / 1$ ).

Herdriocystis sp., Diplophrys sp., Nuclearia sp., Entosiphon sp., Anthophysa sp., Ceratuim sp., Eudorina sp., Astasia sp., Urceolus sp., Cartenia sp., Stentor sp., 
Strombidium sp., Euplotes sp., Cothurnia sp., Urocentrum sp., Coleps sp., Didinium sp., Dileptus sp., Stylonychia sp., Tintinnidium sp., Blepharisma sp., Parurolptus sp., Pleuronema sp., Loxodes sp., Lacrymaria sp., Vaginicola sp., Holotichia sp., Podophyra sp., Chlamydodon sp., Loxophyllum sp., Epistylis sp., Spirostomum sp., Telotrochidium sp., Chaenea sp., Strichotricha sp., Spathidium sp., Acineta sp., Colnilembus sp., Colpidium sp. and Trachelophyllum sp.

Herdriocystis sp. was found to be scattered throughout the year with irregular mode of occurrence, with a maximum count of 5 in July and a minimum count of 1 in April, June and September. Diplophrys sp. appeared in June only, where its density was 5. Nuclearia sp. appeared also in September only with a count of 1.

Entosiphon sp. was found during January (13). Ceratuim sp. existed during January and early Spring (March-April), where its population densities ranged between a minimum of 1 in January and April, and maximum of 4 in March. Anthophysa sp. was observed in January, February, April, July, August, September and November with a maximum value of 18 in July. Eudorina sp. existed during May, June, August and September, where its population densities ranged between a minimum of 5 in June and a maximum of 12 in August.

Astasia sp. existed during two months (September and October) and ranged between four in September to one in October. Urcealus sp. appeared in October only where its density was only one. Cartenea sp. appeared also in October only with a count of 1. Stentor sp. was found to be scattered throughout of the year with irregular mode of occurrence with a maximum count of 6 in February and a minimum count of one. in August. Strombidium sp. existed during October only with a value of 4 .

Euplotes sp. was observed in June, August and March with densities of 17, 6 and 4, respectively. Cothurnia sp. appeared in five months (February, March, April, September and October) with a maximum value of 15 in September and a minimum value of one in February and March.

Urocentrum sp. appeared in January only, where its density was two. Coleps sp. was found during four months (December, June, August and November) with a maximum count of 18, but was only one in August. Didinium sp. appeared in June only, where its density was two. Dileptus sp. was found during February, March, April, May, June and August with a maximum value of 5 in May and a minimum value of one in February, March, June and August. Stylonychia sp. appeared only in March where its density was 1 . Tintinnidium sp. appeared in January only where its density was 6. Blepharisma sp. appeared in June only where its density reached 16. Parurolptus sp. appeared in three months of the year (December, January, April) with a maximum count of 9 in April and a minimum count of one in January. Pleuronema sp. appeared only in four months (January, February, March and November) with the numbers one, three, seven, and one respectively. Loxodes existed during early Spring and Summer (April, May, June and July), where its density ranged between a maximum of 16 in April and a minimum of two in July. Lacrymaria sp. reached its maximum value (3) in July and September, while the minimum value (1) was noticed in April and June. Vaginicola sp. appeared only during early Spring (March and April) by 6 and 3, respectively. Holotrichia sp. was found during March, April, June and November with a maximum count of three in June and a minimum count of one in March and April. Podophyra sp. appeared during three months (December, April and August) with a maximum count of five in April and a minimum count of one organism in December. Chlamydodon sp. appeared only during April and July, where its density was 1 and 2. Loxophyllum sp. existed during August and September, where 
its densities were one and two, respectively. Epistylis sp. appeared only in September with a density of two.

Spirostomum sp. appeared in four months (March, July, September and October) with maximum count of 2 in October and a minimal count of 1 , in the first three months. Telotrochidium sp., Chaenea sp., Colnilembus sp., Colpidium sp., Strichotricha sp., Trachelaphyllum sp. appeared only in one month of a year (November, for the first two genera; January Colnilembus sp., June for Colpidium sp. and Stnchotricha sp. and September for Trachelaphyllum sp.) with a count of 1. Spathidium sp. appeared in December and June (2 and 1). Acineta sp. appeared in December and February, with the number of 3 and 2, respectively.

\section{Rotifera}

It was found that the population densities of Rotifera in raw water samples attained a climax of 86, during April. The second peak of 76 was observed in July. The minimal counts of 14 and 17 were detected in November and December respectively.

\section{Bacterial Investigations}

Total coliform (Tc), fecal coliform (Fc) and Escherichia coli. (E. coli) were counted using Most Propable Number (MPN) method, while Salmonella and Shigella were counted using Spread Plate Method, according to APHA (1998).

Raw water samples showed that MPN of Tc varied from 109 to 390/100 ml in September and July respectively, while those of Fc increased from 2 to 18/100 ml water for Fc observed in November and May respectively. The counts of E. coli fluctuated between 2 and 18/100 ml water with the highest average value observed in May and the lowest average value observed in November, as shown in Table 5. Count for Salmonella and Shigella showed that the highest average numbers were found in September and November, being 153 and 152 CFU/ml, respectively for Salmonella, while the highest average numbers for Shigella were observed in August, June and July (340, 338, and 335 CFU/ml respectively).

Table 5: Monthly occurrence of Bacteria (Total coliform,Tc; fecal coliform, Fc; and E. coli) existed in raw water ( $\mathrm{R}$ ), filtered ( $\mathrm{F}$ ), and tap water at Shebeen Alkoom.

\begin{tabular}{|l|c|c|c|c|c|c|c|c|}
\hline & $\mathrm{R}$ & $\mathrm{R}$ & $\mathrm{R}$ & $\mathrm{R}$ & $\mathrm{R}$ & $\mathrm{F}$ & $\mathrm{F}$ & Tap \\
\hline \multicolumn{1}{|c|}{ Month } & $\mathrm{Tc}$ & $\mathrm{Fc}$ & E. coli & Salmonella & Shigella & Tc & Fc & Tc \\
\hline December 2008 & 260 & 12 & 12 & 89 & 185 & 1 & 1 & 1 \\
\hline January 2009 & 195 & 12 & 12 & 3 & 82 & 1 & 1 & 1 \\
\hline February 2009 & 195 & 11 & 11 & 51 & 258 & 1 & 1 & 1 \\
\hline March 2009 & 285 & 5 & 5 & 68 & 219 & 1 & 1 & 1 \\
\hline April 2009 & 265 & 7 & 7 & 42 & 193 & 4 & 1 & 4 \\
\hline May 2009 & 236 & 18 & 18 & 66 & 157 & 4 & 2 & 2 \\
\hline June 2009 & 307 & 8 & 8 & 68 & 338 & 2 & 1 & 1 \\
\hline July 2009 & 390 & 8 & 8 & 0 & 335 & 2 & 1 & 3 \\
\hline August 2009 & 123 & 5 & 5 & 50 & 340 & 2 & 1 & 2 \\
\hline September 2009 & 109 & 5 & 5 & 153 & 266 & 4 & 1 & 4 \\
\hline October 2009 & 180 & 4 & 4 & 81 & 220 & 1 & 1 & 1 \\
\hline November 2009 & 205 & 2 & 2 & 152 & 147 & 2 & 2 & 1 \\
\hline
\end{tabular}

The lowest average numbers for Salmonella in raw water samples were zero, and 3 CFU /100ml in July and January respectively. For Shigella, the lowest densities 
were 82, $147 \mathrm{CFU} / \mathrm{ml}$ in January and November respectively. In Filtered water samples, the highest average numbers were observed in April, May and September being $4 \mathrm{MPN} / 100 \mathrm{ml}$ for total coliform. Those of Fecal coliform were observed in May and Novemberm, being 2 MNP/100 ml, while E. coli, Salmonella and Shigella were completely absent.

Regarding seasons the highest counts of bacterial indicator Tc in raw water samples were detected in the warmer seasons (Spring and Summer) as shown in Table 6 .

Table 6: Seasonal Variations of Total Coliform, Fecal Coliform andEscherichia coli, Salmonella and Shigella recorded in Raw water.

$\begin{array}{cccccc}\text { Seasons } & \begin{array}{c}\text { Total Coliform } \\ \text { MPN/100ml }\end{array} & \begin{array}{c}\text { Fecal Coliform } \\ \text { MPN/100ml }\end{array} & \begin{array}{c}\text { E. Coli } \\ \text { MPN /100ml }\end{array} & \begin{array}{c}\text { Salmonella } \\ \text { CFU/ml }\end{array} & \text { Shigella CFU/ml } \\ \text { Winter } & 217 & 11 & 11 & 48 & 175 \\ \text { Spring } & 262 & 10 & 10 & 59 & 190 \\ \text { Summer } & 273 & 7 & 7 & 39 & 337 \\ \text { Autumn } & 165 & 3 & 3 & 128 & 211\end{array}$

In treated water, all samples from outlet water treatment were free from total coliform, fecal coliform, E. coli, Salmonella and Shigella groups. These results indicate the safety of treated water according to the Egyptian Standard, (2007) for drinking water. Tap water samples, showed that number of total coliform ranged between 1 and 4 MPN/100 ml, but were free from fecal coliform, E. coli, Salmonella and Shigella groups.

Overall correlations between the studied species and specific variables, are presented in Table 7. From that Table, it is clear that the increase of manganese, ammonia, dissolved oxygen will be accompanied by an increase of protozoan abundance, while Ca and turbidity play a reducing effect on its prevalance. However, a negative relationship between protozoa and rotifers was obtained. Ciliates as a group of protozoa were found to increase by rising in turbidity and/or manganese.

On the other hand, either water temperature or turbidity increases the abundance of rotifers, while alkalinity or total hardness negatively affects their abundance.

Table 7: Correlations coefficient (r) of total protozoa (P), rotifers, ciliates, and certain physico-chemical parameters.

\begin{tabular}{|l|l|l|}
\hline Parameters & Correlation, $\mathrm{r}$ & Type of relation \\
\hline P \& Mn & 0.55 & +ve \\
\hline P \& Ca & 0.60 & -ve \\
\hline P \& Turbidity & 0.55 & -ve \\
\hline P \& Ammonia & 0.58 & +ve \\
\hline P \& DO & 0.57 & +ve \\
\hline P \& Rotifera & 0.44 & -ve \\
\hline P \& Total Coliform & 0.43 & -ve \\
\hline Ciliates \& Turbidity & 0.56 & +ve \\
\hline Ciliates \& Mn & 0.60 & +ve \\
\hline Rotifera \& Alkalinity & 0.64 & -ve \\
\hline Rotifera \&Total hardness & 0.55 & -ve \\
\hline
\end{tabular}

\section{DISCUSSION}

\section{Main Zooplankton (Protozoa and Rotifera)}

The maximum population density of main zooplankton in this study was observed during Autumn and Spring with a peak in April (805 organism x10 $3 / 1)$ and 
September (792 organism $\left.\times 10^{3} / 1\right)$. This might be attributed to the relatively higher water temperature $\left(24.3\right.$ and $22.8^{\circ} \mathrm{C}$, respectively). The rise of water temperature was favored by most plankton organisms as indicated by Forsyth and McCallam, (1980), and Benzie (1984).

Further more, those mentioned periods were characterized by abundant protozoa, which perform major food for zooplankton. That was even emphasized by a significant correlation $(r=0.67)$ between the mentioned communities.

Although physical factors (Benzie, 1984), and chemical conditions (Lind, 1974) were reported to control the abundance of zooplankton, no significant relationships was obtained between these parameters in the present study.

\section{Protozoa}

On considering water pollution, protozoa seem to be an excellent tool to assess both toxicity and pollution: they are regarded as biological indicators of pollution when their presence or absence can be related to particular environmental conditions, and they are considered test organisms when a species or population is used to evaluate the toxicity of relevant toxic compounds (Nicolau et al., 2001). Certain genera of ciliated protists representing healthy environmental conditions, could be employed as biological indicators for system performance process, because there is a strong positive correlation between the abundance of some protozoa and chemical parameters (Scholz and Martin, 1998; Jiang and Shen, 2007).

In the present study, Protozoa persisted all over the year, and they contributed $90.5 \%$ of the total population density of the examined zooplankton in raw water samples. During the present study, the total of 61 genera of protozoa was identified in raw water samples and completely missing in filtered, treated and tap water samples. This may be attributed to the added primary chlorine at the beginning of water treatment, indicating its effectiveness.

Generally, the maximum density of Protozoa was observed during Autumn and Spring with a peak in September and April, which agreed with El-Bassat (1995). Monthly results showed a significant correlation between total protozoa and: manganese, Calcium, Ammonia plus dissolved oxygen. On the other hand, a negative significant correlation was found to occur between population density of protozoa and both rotifers, and total coliform bacteria, which agreed with Sibille et al. (1998); Stevik (1998); Bomo et al. (2004); Chabauda et al. (2006); and Papadimitriou et al. (2010).

Ciliates are considered as important creatures in nutrient recycling (Senler and Yildiz, 2004). Moreover, ciliates respond more quickly to environmental contamination than other organisms because of their high reproduction rates, sensitivity, and variety of occupied niches (bacterivores, algivores, carnivores, omnivores). Changes in species diversity and structure are reliable and generally useful means for assessing the biological effects of pollution (Velho et al., 2005; Madoni and Zangrossi, 2005). Recent studies demonstrated that many periphytic forms play a positive role in improving and maintaining water quality (Zhang and Song, 2000; Zhang et al., 2001a,b; Xu et al., 2004). This could be observed in the present study where monthly results of ciliates showed significant positive and negative correlations with physicochemical parameters. On examining those relationships in further detail, only three ciliate protozoans (Cinetochilum, Lembadion and Lacrymaria spp.) showed significant correlation with ambient temperature. In addition, eight ciliated protozoans (Euplotes, Cyclidium, Didinium, Dileptus, Blepharisma, Holoticha, Strichotricha, Colpidium spp.) showed significant correlation with ammonia. These results agreed with Xu et al. (2004a and 2004b) who 
found that ciliates are likely to play a positive role in maintaining and improving water quality in aquatic environments with high-level ammonium, such as sewage treatment systems.

\section{Rotifera}

Rotifers are sensitive to water quality changes (Marneffe et al., 1996). They are good indicators of saprobity (Authman, 1998). They can be used to indicate the performance of certain types of water treatment process (Spellman, 2003). They have positive correlation with water temperature, turbidity; and a negative one with alkalinity. Previous works indicated that temperature control birth and growth rates of rotifers (Galkovskaga, 1987). Turbidity (Menzel and Roth, 1972; Abd El- Mageed, 1995; and Authman, 1998) and alkalinity (Authman;1998) affects negatively on growth and distribution of rotifers.

\section{Bacterial Investigation}

In raw water samples, the presence of total coliform, fecal coliform, and E. coli indicates that the water was contaminated by fecal material from municipal waste water discharge, or septic leachate (An et al., 2002). Total coliform and E. coli coexist with pathogenic organisms (Salmonella and Shigella). Thus, their presence may reflect the presence of enteric pathogens (USEPA, 1999; An et al., 2002). In a survey by Seyfried and Harris (1990), over 94\% of the thermo tolerant coliforms isolated from human faeces were identified as E. coli. Accordingly, the observed high counts of bacterial indicator (TC), here, were detected in the warmer seasons, (Spring and Summer).

In filtered water samples, total coliform and fecal coliform occurred very scarcely, which may be attributed to contamination of sand filter system by wastes of warmblooded animal such as birds.

In treated water samples, the absence of total coliform, fecal coliform, Salmonella and Shigella groups could be attributed to the effectiveness of disinfection process. These results indicate the safety of treated water according to the WHO (1998) and Egyptian Standards (2007).

In tap water samples, Total coliforms occurred in very few numbers, though should be absent immediately after disinfection, indicating inadequate treatment (WHO, 2008). A number of research studies have shown that coliform bacteria can grow within drinking water distribution systems and can be a significant contributor to biofilm populations (LeChevallier, 1990; Chowdhury, 2012). It has been shown that the presence of significant densities of coliforms within distribution systems represent a health risk to water consumers (Edberg et al., 1994), but can reveal contamination through ingress of foreign material (WHO, 2008). Marciano-Cabral et al. (2010) reported that despite effective treatment of drinking water, microbes can enter water utility distribution systems and hence the plumbing within building premises. Additionally, biofilm formation may add account for the persistence of microbes in the distributing system. These findings indicate that further treatment of drinking water before consumption is essential for avoiding potential health hazards.

\section{REFERENCES}

Abdel-Mageed, A.A. (1995). Studies on zooplankton from lake Nasser Egypt. PhD Thesis, Zool., Dep., Fac., Sci., Alazhar University, Egypt.

American Public Health Association (APHA) (1998). Standard methods for the examination of water and wastewater. $20^{\text {th }}$ ed., Washington, DC. 
An, Y. J.; Kampbell, D.H. and Breidenbach, G.P. (2002). Escherichia coli and total coliforms in water and sediments at lake marinas. Environ. Pollut. 120: 277284.

Authman, M. (1998). A study on fresh water Pollution and its effects on zooplankton and fish -Oreochromis Niloticus- in Shanwan Drainage Canal at Almay, Al Menoufeya Province, Egypt. PhD Thesis, Zool., depart., Fac., Sci., Minofeya University, Egypt.

Benzie, J. A. H. (1984). Zooplankton of Australia, Hifh Alpine Lake, Lake Cootapatamba, Kosciuko Range Augst. J. Mar. Fresh W. Res., 35: 691-702.

Bomo, A.M.; Stevik, T.K.; Hovi, I. and Hanssen, J.F. (2004). Bacterial removal and protozoan grazing in biological sand filters. J. Environ. Qual., 33:1041-1047.

Boothman, S.; Mansfield, J. and Weston, L. (2002). Sources of faecal coliform pollution within the manly lagoon catchments. IN: UTS Freshwater Ecology Report "Department of Environmental Sciences, University of Technology". Sydney.

Chabauda, S.; Yves Andresb, Y.; Lakela, A. and Cloirecb, P.L. (2006). Bacteria removal in septic effluent: Influence of biofilm and Protozoa. Wat. Res., 40: 3109-3149.

Chowdhury, S. (2012). Heterotrophic bacteria in drinking water distribution system: a review. Environ. Monit. Assess., 184: 6087-6137.

Edberg, S.C.; Patterson, J.E. and Smith, D.B. (1994). Differentiation of distribution systems, source water and the clinical coliforms by DNA analysis. J. Clinical Microbiology, 32:139-142.

Egyptian Standards (2007). Egyptian Standards for potable water. Minister’s Office, Dissection No. (458).

El-Bassat, R.A. (1995). Ecological Studies on zooplankton in the river Nile. MSc. Thesis, Dept, Marine Science, Fac. Sci., Suez Canal University.

Forsyth, D.J. and McCallam, L.D. (1980). Zooplankton of Lake Taupo. New Zealand J. Mar. Freshwater. Res. 14: 65-69.

Galkovskaga, G.A. (1987). Planktonic rotifers and temperature. Hydrobiol., 147: 307317.

Hynes, M. (1942): The isolation of intestinal pathogens by selective media. J. Path. Bact., 54: 193- 207.

Jiang, J.G. and Shen, Y.F. (2007). Development of the microbial communities in Lake Donghu in relation to water quality. Environ. Monit. Assess., 127: 227-236.

LeChevallier, M.W. (1990). Coliform regrowth in drinking water. a review. J. Amer. Water Works Assoc., 82:74-86.

Leifson, E. (1935). New culture media based on sodium deoxycholate for the isolation of intestinal pathogens and for the enumeration of colon bacilli in milk and water. J. Path. Bact., 40: 581-599.

Lind, O.T. (1974). Handbook of common methods in limnology. The C.V. Mosby company, saint louis.

MacFaddin, J.F., (1985). Media for Isolation-Cultivation-Identification-Maintenance of Medical Bacteria. Vol. 1. Williams and Wilkins. Baltimore, Maryland.

Madoni, P., and Zangrossi, S. (2005). Ciliated protozoa and saprobical evaluation of water quality in the Taro River (northern Italy). Ita. J. Zool., 72: 21-25.

Marciano-Cabral, F.; Jamerson, M. and Kaneshiro, E.S. (2010). Free-living Amoebae, Legionella and Mycobacterium in tap water supplied by a municipal drinking water utility in the USA. J. Water Health, 8: 71- 82. 
Marneffe, Y.; Descy, J. and Thome J. (1996). the zooplankton of the lower river Meuse, Belgum: Seasonal changes and impact of industrial and municipal discharges . Hydrobiologia, 319: 1-13.

Menzel R. and Roth, F. (1972). Specktrale Phototaxis von plankton rotatorien experiential. 28: 350-357.

Michiels, C.W. and Moyson, E.L.D. (2000). Bacteriological analysis. In: L.M.L. Nollet (Ed.), Handbook of Water Analysis. Marcel Dekker, New York, 115-141.

Nicolau, A.; Dias, N.; Mota, M. and Lima, N. (2001). Trends in the use of protozoa in the assessment of wastewater treatment. Res. Microbiol., 152: 621-630

Papadimitriou, C.A.; Papatheodoulou, A.; Takavakoglou, V.; Zdragas, A.; Samaras, P.; Sakellaropoulos, G.P.; Lazaridou, M. and Zalidis, G. (2010). Investigation of protozoa as indicators of wastewater treatment efficiency in constructed wetlands. Desalination, 250: $378-382$.

Scholz, M. and Martin R. J. (1998). Control of Bio-regenerated Granular Activated Carbon by Spreadsheet Modelling. J. Chem. Technol. Biotechnol., 71: 253261.

Senler, N.G. and Yildiz, Ü. (2004). Faunistic and morphological studies on ciliates (protozoa, Ciliophora) from a small pond, with responses of ciliate populations to changing environmental conditions. Turk. J. Zool., 28:245-265.

Seyfried, P. and Harris, E. (1990). Bacteriological characterization of feces and source differentiation. Water resources branch, Ontario Ministry of the Environment. Queen's Printer for Ontario.

Zhang, S. L., H. G. Ma and W. B. Song, (2001a). Experimental ecology studies on the marine ciliate Paranophrys magna I. The effects of different initial population densities and food conditions on the population growth, Oceanologia et Limnologia Sinica. 32: 25-31.

Zhang, S. L.; Ma, H.G.; Xu, H.L. and W. B. Song, W. B. (2001b). On experimental ecology of the marine ciliate Paranophrys magna IV: effects of competition on population growth. Acta Ecologia Sinica, 21: 2039-2044.

\section{ARABIC SUMMARY}

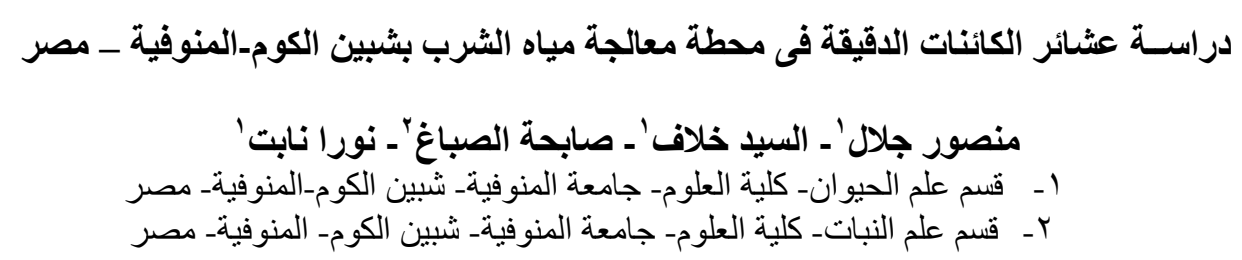

اجريت هذه الدر اسـة بمحطة شبين الكوم الجديدة لمعالجـة ميـاه الثرب، ولقد درست الكائنـات الدقيقة

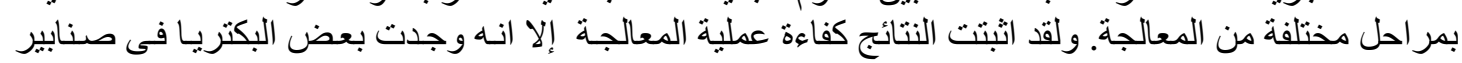

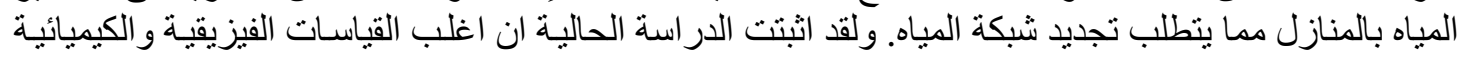

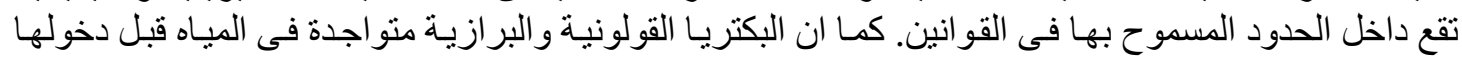

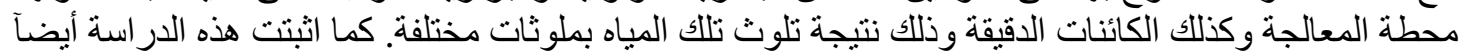

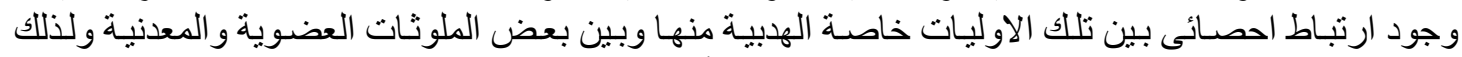

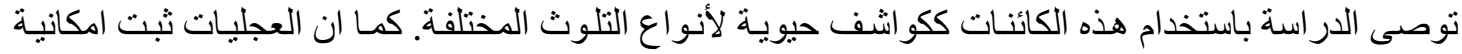
استخدامها للالالة على كفاءة بعض مر احل المد المعالجة. 